\title{
METABOLISM IN IDIOPATHIC STEATORRHEA. II. EFFECT OF LIVER EXTRACT AND VITAMIN D ON CALCIUM, PHOSPHORUS, NITROGEN, AND LIPID BALANCES
}

\author{
By SAMUEL H. BASSETT, E. HENRY KEUTMANN, HENRY VAN ZILE HYDE, \\ HELEN E. VAN ALSTINE \\ (From the Department of Medicine, School of Medicine and Dentistry, University of Rochester, \\ and the Medical Clinic of the Strong Memorial and Rochester Municipal \\ Hospitals, Rochester, New York)
}

(Received for publication August 24, 1938)

Amelioration of the symptoms of tropical sprue, particularly the anemia and gastro-intestinal disturbances, has followed the oral and parenteral administration of liver or liver extracts $(1,2,3$, $4)$. It has been claimed that similar treatment is effective in the treatment of idiopathic steatorrhea (non-tropical sprue) (5). Barker and Rhoads (6), in a study of the blood lipids in sprue, came to the conclusion that liver extract must exert some specific effect on intestinal absorption. The plasma lipids of the treated cases increased after a meal containing fat, while those patients, who received only a sprue diet, failed to show a similar increase during the test. Ross (7), on the other hand, in an investigation of celiac disease (a condition perhaps identical with idiopathic steatorrhea) was unable to demonstrate any effect on the absorption of carbohydrate after injections of liver extract (campolon). He believed that this form of treatment improved the utilization of intravenous glucose.

Whether identical metabolic defects exist in these three diseases is still an open question. It, therefore, seems pertinent to describe the results of balance studies of patients undergoing treatment with liver extract, who have never resided in the tropics and yet have presented the syndrome of sprue. The term idiopathic steatorrhea as used in this connection has been considered synonymous with non-tropical sprue.

This report supplements a previous paper (8) and deals specifically with $(a)$ the effect of parenterally administered liver extract on lipid and mineral balances, $(b)$ the effect of diet and other therapeutic procedures on the level of calcium and inorganic phosphorus in the serum, and $(c)$ the effect of administration of vitamin D concentrates.

\section{PRESENTATION OF DATA}

The four patients whose case histories have been given in detail elsewhere (8) all received parenteral liver extract and a vitamin D concentrate during some period of the investigation. The diets and methods of investigation were the same as those used previously (8).

Liver extract. Three of the patients, J. B., R. G., and P. A., were treated while resident in the metabolic unit. The fourth patient, S. B., received liver therapy while on the general ward and since dietary control was inadequate balances could not be kept. The impressions gained in his case have been summarized in his case report (8). Lilly's liver extract (concentrate, N.N.R.) ${ }^{1}$ was given to the other patients by intramuscular injection.

Case J. B. received $5 \mathrm{ml}$. daily for 6 days (Periods 35 and 36, Table I). At this time she was receiving Diet $\mathrm{V}$ believed to contain 115 grams of fat; the amount actually found at a later analysis was 67 grams. Before this fact was established, the decrease in fecal lipid and the more normal appearance of the stools were considered an effect of the liver extract. Although unable to pursue the investigation further in the metabolism unit, on the return of the patient to the general ward she was induced to take Diet II for a week. Injections of liver were continued and feces were collected on the last 4 days of this period. They were soft and gray. Analysis for fatty acids showed no noticeable change from that of the early control periods while in the metabolic unit.

1 The liver extract was contributed by Eli Lilly and Company, through the courtesy of Mr. George B. Walden. 
TABLE I

Lipid, nitrogen, calcium, and phosphorus metabolism during administration of liver extract

\begin{tabular}{|c|c|c|c|c|c|c|c|c|c|c|c|c|c|c|}
\hline \multirow{2}{*}{ Periods } & \multirow{2}{*}{$\begin{array}{c}\text { Diet } \\
\text { number }\end{array}$} & \multirow{2}{*}{$\begin{array}{c}\text { Number } \\
\text { of days }\end{array}$} & \multirow{2}{*}{$\begin{array}{c}\text { Total } \\
\text { liver } \\
\text { extract }\end{array}$} & \multirow{2}{*}{$\begin{array}{l}\text { Daily } \\
\text { lipid } \\
\text { intake }\end{array}$} & \multicolumn{6}{|c|}{ Daily feces } & \multicolumn{3}{|c|}{ Daily balances } & \multirow{2}{*}{ Weigh } \\
\hline & & & & & Weight & $\begin{array}{l}\text { Fatty } \\
\text { acids }\end{array}$ & $\begin{array}{l}\text { Total } \\
\text { lipid }\end{array}$ & $\mathrm{Ca}$ & $\mathbf{P}$ & $\mathbf{N}$ & Calcium & Phosphorus & Nitrogen & \\
\hline & & & $m l$. & grams & grams & grams & $\begin{array}{l}\text { per cent } \\
\text { of dry } \\
\text { weight }\end{array}$ & grams & grams & grams & grams & grams & grams & kgm. \\
\hline
\end{tabular}

CASE J.B.

\begin{tabular}{|c|c|c|c|c|c|c|c|c|c|c|c|c|c|c|}
\hline $\begin{array}{l}\text { Control } 7-11 \ldots \\
\text { Liver } 35^{*} \ldots \ldots \\
\text { Liver } 36^{*} \ldots \ldots \\
\text { Liver } 37 \dagger \ldots \ldots\end{array}$ & $\begin{array}{l}\text { II } \\
\mathbf{V}^{*} \\
\mathbf{V}^{*} \\
\text { II }\end{array}$ & $\begin{array}{r}15 \\
3 \\
3 \\
4\end{array}$ & $\begin{array}{c}\text { None } \\
15 \\
15 \\
16\end{array}$ & $\begin{array}{r}100 \\
67 \\
67 \\
100\end{array}$ & $\begin{array}{r}197 \\
167 \\
85\end{array}$ & $\begin{array}{r}15.0 \\
11.3 \\
6.4 \\
14.3\end{array}$ & $\begin{array}{l}37.5 \\
34.7 \\
30.2 \\
40.0\end{array}$ & $\begin{array}{l}1.33 \\
1.37 \\
0.86\end{array}$ & $\begin{array}{l}0.73 \\
0.58 \\
0.38\end{array}$ & $\begin{array}{l}1.59 \\
1.85 \\
1.11\end{array}$ & $\begin{array}{r}-0.08 \\
-0.44 \\
+0.08\end{array}$ & $\begin{array}{l}+0.06 \\
-0.12 \\
+0.01\end{array}$ & $\begin{array}{l}-0.14 \\
+0.74 \\
+0.91\end{array}$ & $\begin{array}{l}47.25 \\
47.73 \\
48.69\end{array}$ \\
\hline
\end{tabular}

CASE R.G.

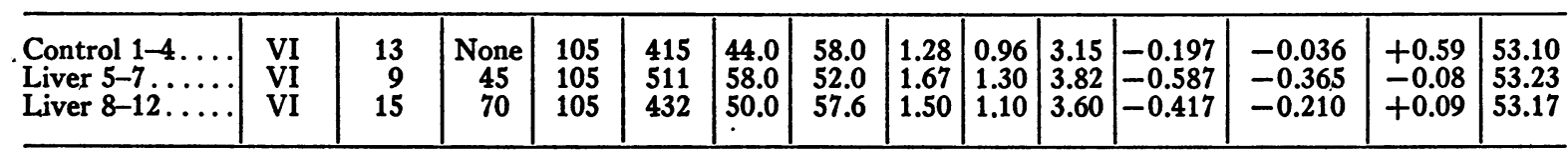

CASE P.A.

\begin{tabular}{l|l|l|c|c|c|c|c|c|c|c|c|c|c|c}
\hline Control 1-3.... & VI & 12 & None & 105 & 185 & 11.5 & 32.5 & 0.96 & 0.53 & 2.62 & +0.103 & -0.002 & +0.36 & 44.82 \\
Liver 4-8...... & VI & 27 & 115 & 105 & 174 & 11.8 & 36.0 & 0.98 & 0.51 & 2.35 & +0.074 & +0.017 & +0.81 & 46.08 \\
Liver 9-10..... & VI & 12 & 55 & 105 & 166 & 11.8 & 36.0 & 0.92 & 0.41 & 2.31 & +0.153 & +0.093 & +1.48 & 46.56 \\
Liver 14-16.... & VII & 12 & 30 & & & & & & & & & \\
Liver 17-19.... & VI & 15 & 30 & 105 & 178 & 12.3 & 34.3 & 1.04 & 0.61 & 2.56 & +0.019 & +0.058 & +0.86 & 47.48 \\
\hline
\end{tabular}

* Control on Diet V not obtained. See text for interpretation of results.

t Period 37 carried out on general medical division.

It seems unlikely that the liver extract was responsible for the improvement in steatorrhea, rather the decrease in fecal lipid was the result of a different diet and a lower intake of fat. The results demonstrate the advisability of actually analyzing the diet for fat rather than depending upon an estimation of the amount of fat based upon published tables.

Both Cases R. G. and P. A. were given Diet VI and after suitable control periods the daily administration of liver extract was begun without change of diet. R. G. received 27 consecutive intramuscular injections of liver extract of $5 \mathrm{cc}$. each. Data typical of this experiment have been summarized in Table I. No effects were noted which could be attributed to the medication. There was no increase in reticulocytes, and the number of red blood cells and the concentration of hemoglobin remained unaffected. After the close of Period 13 no metabolic observations were made for a week owing to a mild respiratory infection. Beginning with Period 14 the diet was changed to one low in calcium (Diet VII) but the intake of fat was maintained at the previous level. Injections of liver were continued for eleven days more. There was still no effect attributable to the medication.

Case P. A. was given 34 intramuscular injections of liver "extract of $5 \mathrm{ml}$. each. An occasional day was missed but the injections were in the main consecutive. His anemia remained unchanged. Fecal weight decreased moderately but the amount of fatty acid excreted daily did not differ from the control periods. While receiving an adequate intake of calcium and phosphorus, balances of these elements were for the most part consistently positive, as were nitrogen balances. Analysis of the results obtained in individual periods revealed no evidence that the slightly greater retentions of calcium, phosphorus, and nitrogen in Periods 9 and 10 (Table I) were more than a matter of chance. It is highly improbable that they were in any way connected with the administration of the liver.

Effect of diet during vitamin $D$ deficiency on the concentrations of calcium and phosphorus in 
the serum. Case $J . B$. The inverse relation between $\mathrm{Ca}$ and inorganic $\mathrm{P}$ in the serum presumably accounted for the lower calcium while ingesting Diets I and II and the higher calcium when on Diet III (9). (See Figure 1.) Analysis of the dietary factors associated with these changes brings out the following points: The $\mathrm{Ca}: \mathrm{P}$ ratio of the high fat diet was 0.8 and of the low 1.23. These two diets caused a marked difference in the paths of phosphorus excretion. On the high fat diet with the low $\mathrm{Ca}: \mathrm{P}$ ratio (Diets I and II) the excretion of urinary phosphorus was about twice as great as on the low fat diet. The diversion of phosphorus from the bowel on this diet is explicable on two grounds, (a) the low $\mathrm{Ca}: \mathrm{P}$ ratio left an excess of phosphorus uncombined with alkaline earths in the intestine which was then absorbed and excreted in the urine, $(b)$ the combination of calcium with fatty acids to form soaps (10) decreased the amount of phosphorus bound to alkaline earths still further and left more phosphorus available for absorption and excretion in the urine (Table II).

The rise in concentration of inorganic phosphorus in the serum seems to have been the result of this greater absorption of phosphorus, and the ultimate effect the same as the administration of an inorganic phosphate by mouth during a later period (Period 22, Figure 1), when tetany was produced. The ease with which tetany may be induced by increasing the intake of phosphorus in vitamin $\mathrm{D}$ deficient children and rats has been discussed by Karelitz and Shohl (11). The adult patient with steatorrhea and $\mathrm{D}$ avitaminosis is no exception to this rule, for the administration of an inorganic phosphate or a diet with low $\mathrm{Ca}: \mathrm{P}$ ratio and high content of fat is capable, in some instances at least, of depressing the concentration of calcium in the serum to dangerously low levels.

Although there was definite evidence of loss of calcium and phosphorus from the body when the low fat diet with a high $\mathrm{Ca}: \mathrm{P}$ ratio (Diet
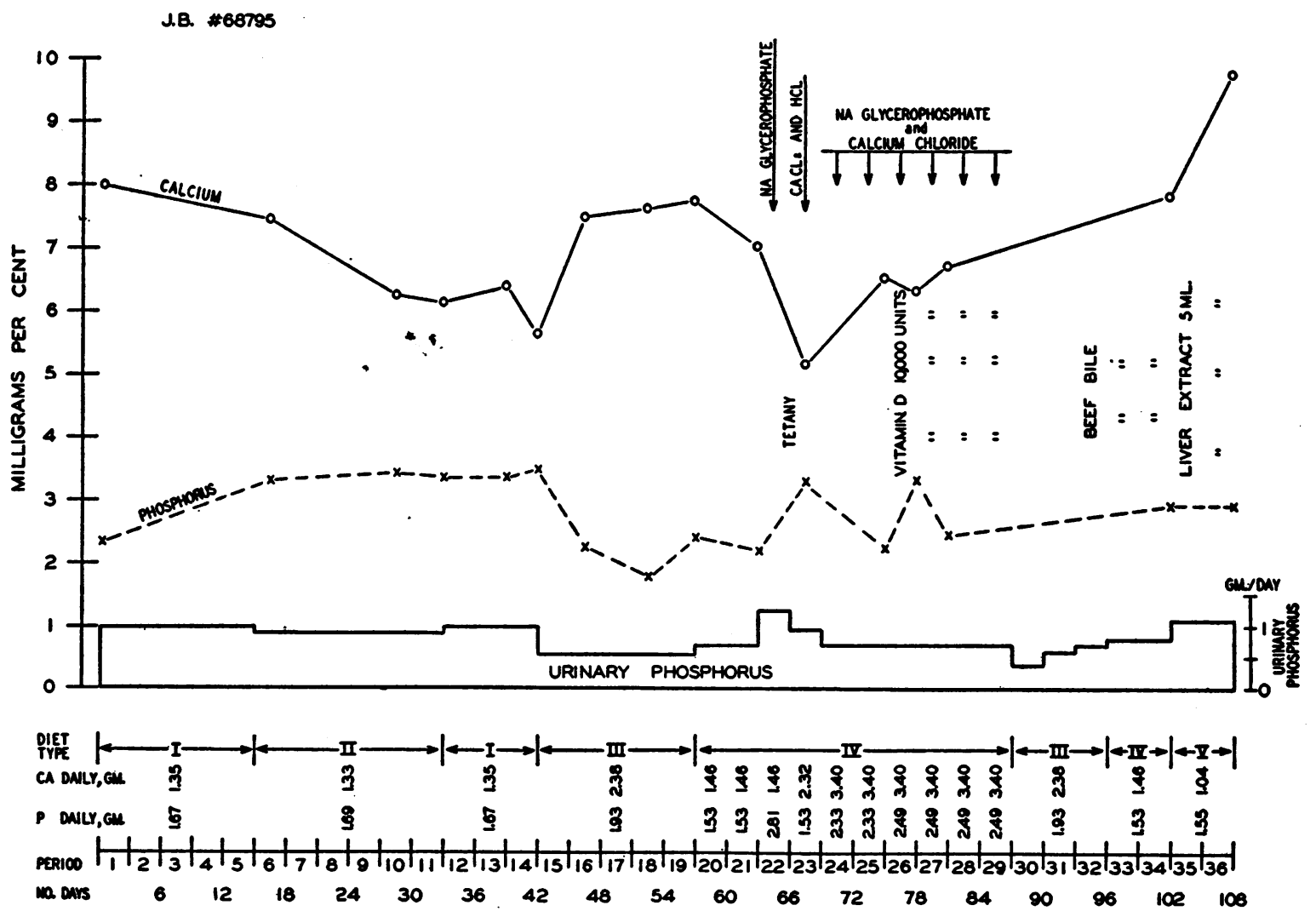

Fig. 1. Effect of Diet and Medication on the Serum Calcium and Inorganic Phosphorus of Patient J. B. 
TABLE II

Fat, calcium, and phosphorus metabolism in Case J.B.

\begin{tabular}{|c|c|c|c|c|c|c|c|c|c|c|c|}
\hline \multirow{2}{*}{ Periods } & \multirow{2}{*}{$\begin{array}{l}\text { Number } \\
\text { of days }\end{array}$} & \multicolumn{3}{|c|}{ Diet } & \multirow{2}{*}{ Daily medication } & \multicolumn{3}{|c|}{ Daily calcium balance } & \multicolumn{3}{|c|}{ Daily phosphorus balance } \\
\hline & & Number & $\begin{array}{l}\text { Fatty } \\
\text { acid }\end{array}$ & $\begin{array}{c}\mathrm{Ca}: \mathrm{P} \\
\text { ratio }\end{array}$ & & Urine & Stool & Balance & Urine & Stool & Balance \\
\hline $\begin{array}{c}1-5 \\
7-11 \\
12-13 \\
16-19 \\
22 \\
23 \\
26-29 \\
30 \\
31 \\
32 \\
33 \\
34\end{array}$ & $\begin{array}{r}15 \\
15 \\
6 \\
12 \\
3 \\
3 \\
12 \\
3 \\
3 \\
3 \\
3 \\
3\end{array}$ & $\begin{array}{l}\text { I } \\
\text { II } \\
\text { I } \\
\text { III } \\
\text { IV } \\
\text { IV } \\
\text { IV } \\
\text { III } \\
\text { III } \\
\text { III } \\
\text { IV } \\
\text { IV }\end{array}$ & $\begin{array}{l}\text { grams } \\
\text { per day } \\
104 . \\
100 . \\
104 . \\
2.8 \\
113.4 \\
113.4 \\
11.4 \\
2.8 \\
2.8 \\
2.8 \\
113.4 \\
113.4\end{array}$ & $\begin{array}{l} \\
0.8 \\
0.8 \\
0.8 \\
1.23 \\
0.52^{*} \\
1.52^{*} \\
1.37^{*} \\
1.23 \\
1.23 \\
1.23 \\
0.95 \\
0.95\end{array}$ & $\begin{array}{l}\text { Vitamin D i.m. } 10,000 \text { units } \\
\text { Beef bile } 3.3 \text { grams } \\
\text { Beef bile } 1.5 \text { grams } \\
\text { Beef bile } 1.25 \text { grams }\end{array}$ & $\begin{array}{l}\text { grams } \\
0.07 \\
0.08 \\
0.08 \\
0.11 \\
0.04 \\
0.05 \\
0.06 \\
0.06 \\
0.07 \\
0.10 \\
0.06 \\
0.07\end{array}$ & $\begin{array}{l}\text { grams } \\
1.26 \\
1.33 \\
1.23 \\
2.47 \\
2.32 \\
2.13 \\
3.46 \\
2.91 \\
2.12 \\
2.39 \\
2.45 \\
1.27\end{array}$ & $\begin{array}{c}\text { grams } \\
+0.02 \\
+0.08 \\
+0.04 \\
-0.20 \\
-0.90 \\
+0.14 \\
-0.12 \\
-0.59 \\
+0.19 \\
-0.11 \\
-1.05 \\
+0.12\end{array}$ & $\begin{array}{l}\text { grams } \\
1.07 \\
0.90 \\
1.06 \\
0.59 \\
1.29 \\
0.93 \\
0.78 \\
0.40 \\
0.63 \\
0.46 \\
0.78 \\
0.79\end{array}$ & $\begin{array}{l}\text { grams } \\
0.45 \\
0.73 \\
0.57 \\
1.36 \\
1.67 \\
1.11 \\
1.71 \\
1.57 \\
1.25 \\
1.35 \\
1.30 \\
0.68\end{array}$ & $\begin{array}{c}\text { grams } \\
+0.15 \\
+0.06 \\
+0.04 \\
-0.02 \\
-0.15 \\
-0.51 \\
0.00 \\
-0.04 \\
+0.05 \\
-0.12 \\
-0.55 \\
+0.06\end{array}$ \\
\hline
\end{tabular}

Observations discontinued for five days

\begin{tabular}{l|l|l|l|l|l|l|l|l|l|l|l}
\hline 35 & 3 & $\mathrm{~V}$ & 67. & 0.67 & Liver extract $5 \mathrm{ml}$. & 0.11 & 1.37 & -0.44 & 1.09 & 0.58 & -0.12 \\
36 & 3 & $\mathrm{~V}$ & 67. & 0.67 & Liver extract $5 \mathrm{ml}$. & 0.10 & 0.86 & +0.08 & 1.16 & 0.38 & +0.01 \\
\hline
\end{tabular}

* Includes $\mathrm{Ca}$ given as $\mathrm{CaCl}_{2}$ and $\mathrm{P}$ given as sodium glycerophosphate.

III) was given to J. B., serum calcium increased and serum inorganic phosphorus decreased (Figure 1 and Table II, Periods 15 to 19). The serum proteins varied between 6.0 and 6.5 grams per cent in Periods 12 to 19 and do not appear to have been a factor in increasing the calcium concentration. From the work of Liu et al. (12) a high $\mathrm{Ca}: \mathrm{P}$ ratio in a diet may be expected to decrease the concentration of inorganic $P$ in the serum and to decrease its excretion in the urine. When the dietary $\mathrm{Ca}: \mathrm{P}$ ratio was above 1 and the amount of fatty acids in the feces negligible (Periods 15 to 19), a large part of the phosphorus entering the intestine was fixed there as an insoluble phosphate of calcium. The absorption of phosphorus was depressed and its concentration in the serum lowered.

Case $R . G$. While the explanation given above seemed valid for J. B., interpretation of the data in Case R. G. (Figure 2) proved to be much more difficult. The levels of calcium and inorganic phosphorus in the serum were determined on numerous occasions, but were omitted in Periods 14 to 17 when the intakes of calcium and phosphorus were lowest. It is, therefore, possible that Figure 2 does not present an entirely unbiased picture of the changes in the blood. These periods would have been of considerable interest since most of the dietary phosphorus appears to have been excreted in the feces (Table III).

In spite of the deficiencies in analysis of the blood, there were enough data to demonstrate a considerable degree of constancy in the level of serum inorganic phosphorus prior to treatment with vitamin $D$. In view of the findings in the previous case this was quite unexpected, for the intake, absorption, and urinary excretion of phosphorus varied considerably. The serum calcium on the other hand fluctuated in much the same manner as in Patient J. B. The highest level of calcium was observed at the close of Period 19 when calcium equilibrium had been established for a few days, and was apparently the result of the effect of the low fat diet; the lowest serum calcium occurred after two days of diarrhea brought on by ingestion of the high fat diet which was given in Period 30. The balances of lime and phosphorus at this time were not excessively negative when compared with previous periods on the same diet, and the low level of calcium in the blood can hardly be accounted for on the basis of rapid excretion of calcium into the bowel.

When one considers serum calcium and inorganic phosphorus together, it is clear that some factor, other than an inverse relation between the 


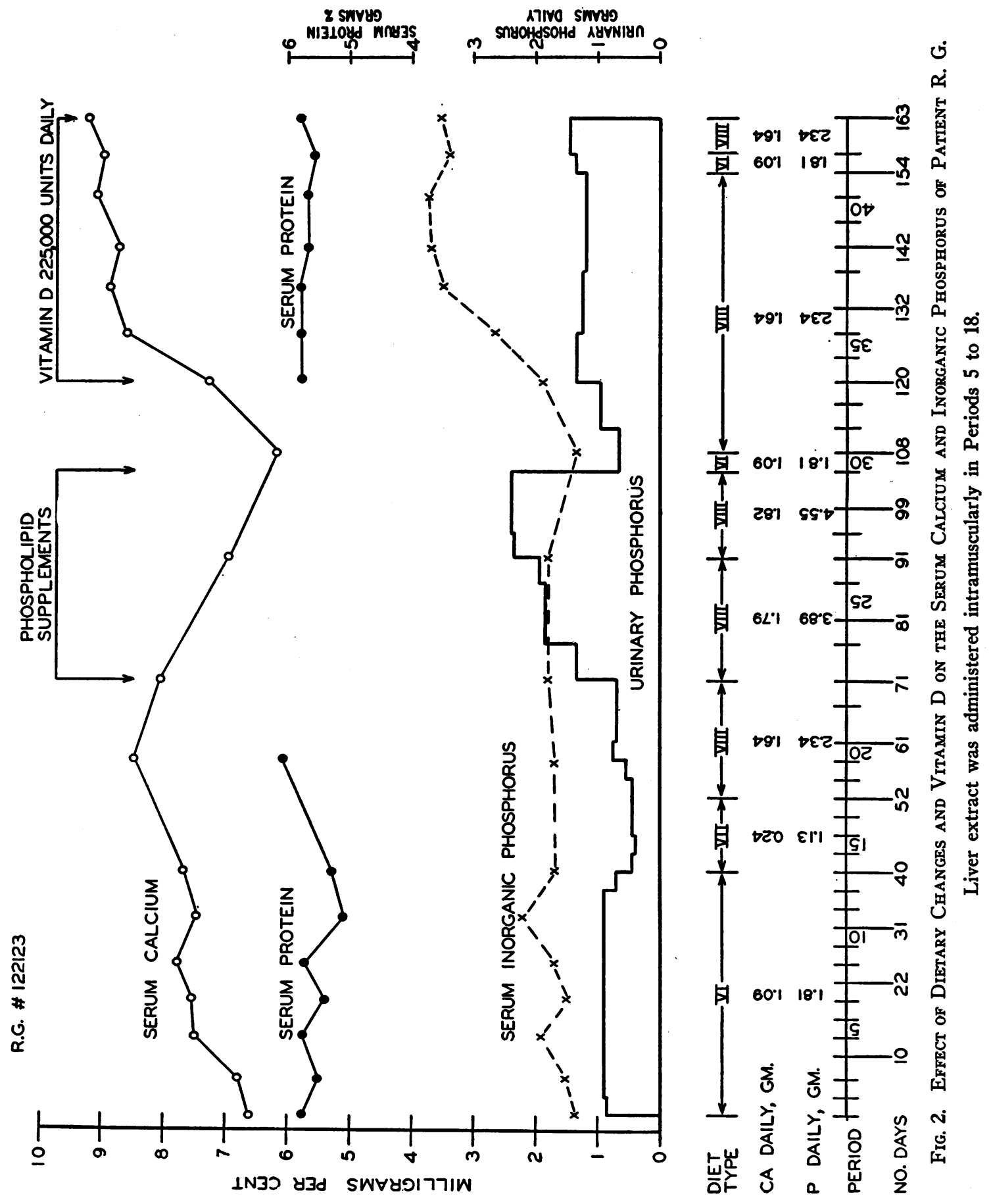


TABLE III

Case R.G. Fat, calcium, and phosphorus metabolism

(All values are daily averages for the respective periods)

\begin{tabular}{|c|c|c|c|c|c|c|c|c|c|c|c|c|c|c|c|c|c|c|}
\hline \multicolumn{2}{|c|}{ Period } & \multicolumn{5}{|c|}{ Diet } & \multicolumn{2}{|c|}{ Feces } & \multicolumn{4}{|c|}{ Exoretion } & \multicolumn{3}{|c|}{ Balances } & \multicolumn{3}{|c|}{ Serum* } \\
\hline \multirow{2}{*}{ Number } & \multirow{2}{*}{ Days } & \multirow{2}{*}{ Number } & \multirow{2}{*}{$\begin{array}{l}\text { Supplement or } \\
\text { medication }\end{array}$} & \multirow{2}{*}{$\begin{array}{l}\text { Fatty } \\
\text { acid }\end{array}$} & \multirow{2}{*}{$\mathbf{C a}$} & \multirow{2}{*}{$\mathbf{P}$} & \multirow{2}{*}{ Weight } & \multirow{2}{*}{$\begin{array}{l}\text { Fatty } \\
\text { acid }\end{array}$} & \multicolumn{2}{|c|}{ Calcium } & \multicolumn{2}{|c|}{ Phosphorus } & \multirow{2}{*}{$\mathrm{Ca}$} & \multirow{2}{*}{$\mathbf{P}$} & \multirow{2}{*}{$\mathbf{N}$} & \multirow{2}{*}{$\mathrm{Ca}$} & \multirow{2}{*}{$\mathbf{P}$} & \multirow{2}{*}{$\begin{array}{l}\text { Total } \\
\text { protein }\end{array}$} \\
\hline & & & & & & & & & Urine & Stool & Urine & Stool & & & & & & \\
\hline $\begin{array}{l}1 \\
2 \\
3 \\
4 \\
5 \\
6 \\
7-8 \\
9 \\
10 \\
11 \\
12 \\
13 \\
14-17 \\
18 \\
19\end{array}$ & $\begin{array}{r}\mathbf{3} \\
\mathbf{3} \\
\mathbf{4} \\
\mathbf{3} \\
\mathbf{3} \\
\mathbf{3} \\
\mathbf{6} \\
\mathbf{3} \\
\mathbf{3} \\
\mathbf{3} \\
\mathbf{3} \\
\mathbf{3} \\
\mathbf{1 2} \\
\mathbf{3} \\
\mathbf{3}\end{array}$ & $\begin{array}{l}\text { VI } \\
\text { VI } \\
\text { VI } \\
\text { VI } \\
\text { VI } \\
\text { VI } \\
\text { VI } \\
\text { VI } \\
\text { VI } \\
\text { VI } \\
\text { VI } \\
\text { VI } \\
\text { VII } \\
\text { VII } \\
\text { VII } \\
\text { VIII }\end{array}$ & $\begin{array}{l}\text { Liver extract } 5 \mathrm{ml} . \\
\text { Liver extract } 5 \mathrm{ml} . \\
\text { Ijver extract } 5 \mathrm{ml} . \\
\text { Liver extract } 5 \mathrm{ml} . \\
\text { Liver extract } 5 \mathrm{ml} . \\
\text { Liver extract } 5 \mathrm{ml} . \\
\text { Liver extract } 5 \mathrm{ml} . \\
\text { Liver extract } 5 \mathrm{ml} . \\
\text { Liver extract } 5 \mathrm{ml} .\end{array}$ & $\begin{array}{l}\text { grams } \\
104.0 \\
104.0 \\
104.0 \\
104.0 \\
104.0 \\
104.0 \\
104.0 \\
104.0 \\
104.0 \\
104.0 \\
104.0 \\
104.0 \\
105.0 \\
15.5 \\
15.5\end{array}$ & $\begin{array}{l}\text { grams } \\
1.092 \\
1.092 \\
1.092 \\
1.092 \\
1.092 \\
1.092 \\
1.092 \\
1.092 \\
1.092 \\
1.092 \\
1.092 \\
1.092 \\
0.229 \\
1.090 \\
1.090\end{array}$ & $\begin{array}{l}\text { grams } \\
1.808 \\
1.808 \\
1.808 \\
1.808 \\
1.808 \\
1.808 \\
1.808 \\
1.808 \\
1.808 \\
1.808 \\
1.808 \\
1.808 \\
1.017 \\
1.561 \\
1.561 \\
\end{array}$ & $\begin{array}{c}\text { grams } \\
\\
\mathbf{3 5 9} \\
\mathbf{1 9 8} \\
\mathbf{5 0 3} \\
\mathbf{3 9 2} \\
\mathbf{6 9 7} \\
\mathbf{3 2 4} \\
\mathbf{5 1 6} \\
\mathbf{2 4 2} \\
\mathbf{4 9 8} \\
\mathbf{5 4 1} \\
\mathbf{3 7 8} \\
\mathbf{7 4 4} \\
\mathbf{5 1 9} \\
\mathbf{3 1 0}\end{array}$ & $\begin{array}{l}\text { grams } \\
\\
36.2 \\
22.6 \\
64.8 \\
45.7 \\
67.3 \\
44.3 \\
63.3 \\
30.1 \\
56.3 \\
60.4 \\
42.2 \\
68.1 \\
32.7 \\
10.9\end{array}$ & \begin{tabular}{|l|} 
grams \\
\\
0.005 \\
0.003 \\
0.005 \\
0.006 \\
0.005 \\
0.005 \\
0.007 \\
0.007 \\
0.009 \\
0.008 \\
0.009 \\
0.006 \\
0.005 \\
0.005
\end{tabular} & $\begin{array}{l}\text { grams } \\
\\
1.308 \\
0.670 \\
1.830 \\
1.146 \\
2.173 \\
1.095 \\
1.782 \\
1.013 \\
1.653 \\
1.676 \\
1.353 \\
1.813 \\
0.624 \\
0.980\end{array}$ & $\begin{array}{l}\text { grams } \\
0.840 \\
0.896 \\
0.895 \\
0.903 \\
0.860 \\
0.836 \\
0.927 \\
0.986 \\
0.916 \\
0.866 \\
0.886 \\
0.790 \\
0.455 \\
0.463\end{array}$ & $\begin{array}{l}\text { grams } \\
\\
0.968 \\
0.508 \\
1.322 \\
0.916 \\
1.836 \\
0.785 \\
1.285 \\
0.720 \\
1.243 \\
1.300 \\
0.956 \\
1.513 \\
0.879 \\
0.800\end{array}$ & \begin{tabular}{|c|} 
grams \\
\\
-0.221 \\
+0.419 \\
-0.743 \\
-0.060 \\
-1.086 \\
-0.008 \\
-0.697 \\
+0.072 \\
-0.570 \\
-0.592 \\
-0.270 \\
-0.727 \\
-0.400 \\
+0.105
\end{tabular} & $\begin{array}{r}\text { grams } \\
0.000 \\
+0.404 \\
-0.409 \\
-0.011 \\
-0.888 \\
+0.187 \\
-0.404 \\
+0.102 \\
-0.351 \\
-0.358 \\
-0.034 \\
-0.495 \\
-0.317 \\
+0.198\end{array}$ & $\begin{array}{r}\text { grams } \\
+1.30 \\
+1.91 \\
-0.81 \\
+0.43 \\
-1.53 \\
+1.66 \\
-0.38 \\
-0.66 \\
+1.36 \\
-0.05 \\
+0.66 \\
-0.03 \\
-0.43 \\
+0.70\end{array}$ & $\begin{array}{c}\text { mom. } \\
\text { per } \\
\text { cent } \\
6.67^{(1)} \\
6.82^{(1)} \\
7.54(1) \\
7.63(8) \\
7.8^{(1)} \\
7.48^{(2)} \\
7.68^{(3)}\end{array}$ & $\begin{array}{c}\text { mom. } \\
\text { per } \\
\text { cent } \\
1.36 \\
1.54 \\
1.92 \\
1.51 \\
1.69 \\
2.2 \\
1.73\end{array}$ & $\begin{array}{c}\text { grams } \\
\text { per } \\
\text { cent } \\
5.74 \\
5.53 \\
5.74 \\
5.41 \\
5.71 \\
5.11 \\
5.30\end{array}$ \\
\hline 20 & 3 & $\begin{array}{l}+ \\
50 \% \\
\text { vIII }\end{array}$ & & 23.2 & 1.635 & $2.342\}$ & 140 & 9.5 & 0.010 & 1.460 & 0.655 & 1.226 & -0.108 & +0.070 & +1.48 & $8.53(1)$ & 1.72 & 6.17 \\
\hline 21-22 & 10 & & & 23.2 & 1.635 & 2.342 & 155 & 6.7 & 0.016 & 1.942 & 0.698 & 1.537 & -0.323 & +0.106 & +1.63 & & & \\
\hline 23 & 6 & & $\begin{array}{l}\text { Phospholipid } \\
50 \text { grams }\end{array}$ & 67.4 & 1.790 & 3.890 & 163 & & 0.009 & 1.850 & 1.351 & 1.730 & -0.069 & +0.809 & +3.03 & $8.1^{(1)}$ & 1.76 & \\
\hline 24-26 & 14 & VIII & $\begin{array}{l}\text { Phospholipid } \\
50 \text { grams }\end{array}$ & 67.4 & 1.790 & 3.890 & 209 & & 0.012 & 1.973 & 1.861 & 1.844 & -0.198 & +0.183 & +2.40 & & & \\
\hline 27 & 4 & $\begin{array}{c}\text { VIfl } \\
+\end{array}$ & $\begin{array}{l}\text { Phospholipid } \\
70 \text { grams }\end{array}$ & 67.6 & 1.820 & 4.545 & 220 & & 0.012 & 1.992 & 2.355 & 2.047 & -0.184 & +0.143 & +2.28 & 7.02 & 1.78 & \\
\hline $28-29$ & 10 & $\frac{\text { VIII }}{+}$ & $\begin{array}{l}\text { Phosphollpid } \\
70 \text { grams }\end{array}$ & 67.6 & 1.820 & 4.545 & 193 & & 0.010 & 1.837 & 2.417 & 1.811 & -0.026 & +0.317 & +2.42 & & & \\
\hline 30 & 3 & $\begin{array}{l}\text { VI } \\
\text { VIII } \\
\text { VIII }\end{array}$ & None & 104.0 & 1.092 & 1.808 & 1067 & 55.6 & 0.005 & 1.166 & 0.703 & 1.470 & -0.079 & -0.365 & +0.68 & $6.18^{(3)}$ & 1.35 & \\
\hline $31-33$ & 12 & & None & 23.2 & 1.635 & 2.342 & 232 & 7.6 & 0.008 & 1.558 & 0.863 & 1.240 & +0.069 & +0.239 & +1.51 & & & \\
\hline 34 & 4 & & $\begin{array}{l}\text { Vitamin D } \\
225.000 \text { I.U. }\end{array}$ & 23.2 & 1.635 & 2.342 & 160 & 4.5 & 0.019 & 1.797 & 1.335 & 1.195 & -0.181 & -0.188 & +1.45 & $7.3^{(1)}$ & 1.79 & 5.80 \\
\hline 35 & 4 & $\begin{array}{c}\text { VIII } \\
+ \\
50 \%\end{array}$ & $\begin{array}{l}\text { Vitamin D } \\
225,000 \text { I.U. }\end{array}$ & 23.2 & 1.635 & 2.342 & 135 & 6.0 & 0.034 & 1.170 & 1.327 & 0.472 & +0.431 & +0.543 & +1.72 & & & \\
\hline 36 & 4 & $\begin{array}{c}\text { VIII } \\
+ \\
50 \%\end{array}$ & $\begin{array}{l}\text { Vitamin D } \\
225,000 \text { I.U. }\end{array}$ & 23.2 & 1.635 & 2.342 & 183 & 7.6 & 0.015 & 0.867 & 1.322 & 0.499 & +0.753 & +0.521 & +0.18 & $8.59(1)$ & 2.66 & 5.77 \\
\hline 37 & 6 & $\begin{array}{c}\text { vill } \\
+ \\
50 \%\end{array}$ & $\begin{array}{l}\text { Vitamin D } \\
225,000 \\
\text { I.U. }\end{array}$ & 23.2 & 1.635 & 2.342 & 80 & 4.5 & 0.016 & 0.370 & 1.026 & 0.249 & +1.249 & +1.067 & +1.72 & $8.94(4)$ & 8.49 & 5.80 \\
\hline 38 & 4 & $\begin{array}{c}\text { VIII } \\
+ \\
50 \%\end{array}$ & $\begin{array}{l}\text { Vitamin } \underset{\text { butter }}{\mathbf{5 0}}+\mathbf{g r a m s} \\
\text { gram }\end{array}$ & 68.2 & 1.635 & 2.342 & 138 & 11.2 & 0.009 & 0.617 & 1.187 & 0.332 & +1.009 & +0.823 & +1.74 & & & \\
\hline 39 & 4 & $\underset{50 \%}{\text { vill }}$ & Vitamin $\underset{\text { butter } 50 \text { grams }}{\mathrm{D}}$ & 68.2 & 1.635 & 2.342 & 97 & 6.9 & 0.015 & 0.450 & 1.245 & 0.211 & +1.170 & +0.886 & +2.05 & $8.70^{(1)}$ & 3.70 & 5.70 \\
\hline 40 & 4 & $\begin{array}{c}\text { VIII } \\
+ \\
50 \%\end{array}$ & $\begin{array}{l}\text { Vitamin } \\
\text { butter } \mathbf{5 0} \text { grams }\end{array}$ & 68.2 & 1.635 & 2.342 & 123 & 7.7 & 0.022 & 0.520 & 1.190 & 0.325 & +1.093 & +0.827 & +1.34 & . & & \\
\hline 41 & 4 & $\underset{50 \%}{+V_{1}^{+1}}$ & $\underset{\text { butter }}{75} \underset{\text { grams }}{\text { Vitamin }}$ & 90.7 & 1.635 & 2.342 & 87 & 6.6 & 0.022 & 0.400 & 1.192 & 0.204 & +1.213 & +0.846 & +3.05 & $9.17^{(1)}$ & 3.76 & 5.70 \\
\hline 42 & 3 & $\mathrm{VI}^{\prime}$ & Vitsmin D & 104.0 & 1.092 & 1.808 & 390 & 24.2 & 0.005 & 0.846 & 1.340 & 0.410 & +0.241 & +0.058 & -0.34 & $9.07^{(3)}$ & 3.46 & \\
\hline 43 & 6 & $\begin{array}{c}\text { VIII } \\
+ \\
50 \%\end{array}$ & $\begin{array}{l}\text { Vitamin D } \\
225,000 \text { I.U. }\end{array}$ & 23.2 & 1.635 & 2.342 & 126 & 10.1 & 0.013 & 0.641 & 1.435 & 0.300 & +0.981 & +0.607 & +1.36 & $8.24^{(6)}$ & 3.56 & 5.80 \\
\hline
\end{tabular}

* Numbers in parenthesis refer to the day of period on which blood was taken.

two, must have affected the level of calcium. Factors which might tend to elevate calcium were (1) a state of equilibrium with the diet as apposed to a previously negative calcium balance,
(2) better absorption of vitamin D from the diet, (3) a higher concentration of protein in the serum, and (4) greater activity of the parathyroid glands. With the exception of the calcium 
balance there was no evidence of the possible effect of any of these factors, and even the evidence derived from a survey of the balances proves to be rather contradictory (Periods 18 to 30).

In attempting to explain the whole situation one might hypothecate a more active participation of the parathyroids in the mechanism for regulating the serum calcium and phosphorus of the second patient (R. G.). The rapid and severe drain upon his reserves of calcium which resulted from steatorrhea and D avitaminosis would, according to the suggestion of Albright and Sulkowitch (13), lower the calcium of the serum and stimulate the parathyroid apparatus. This in turn would accelerate the decalcification of bone, tend to raise the calcium of the serum and depress the inorganic phosphorus by hastening its excretion in the urine. If the rate of excretion of phosphorus by the kidney were sufficiently rapid, no appreciable rise of inorganic phosphorus in the blood would occur, unless the amount passing into the blood from the intestine were very large. Telfer has suggested that there is a primary defect in the absorption of phosphorus in celiac disease (14). The data we obtained while observing the effect of vitamin $D$ lend some support to this concept. Nevertheless, even in the most severe cases of the disease, considerable quantities of phosphorus were absorbed and excreted in the urine, and it is possible that the limiting factors were diarrhea and the presence of large quantities of calcium in the bowel with which phosphorus may have combined to form insoluble phosphates.

Vitamin D. Skeletal decalcification, excessive loss of calcium in the feces, low serum calcium and inorganic phosphorus, and failure to absorb calcium when there was no steatorrhea all pointed to a deficiency of vitamin D in Subjects J. B., R. G., and S. B.

When studying the first patient, J. B., it was feared that even a vitamin $D$ concentrate might escape absorption if given by mouth while the intake of fat was high. To avoid this possibility one gram of a solution of viosterol in oil (Squibb) was given daily by intramuscular injection for 12 days (Periods 26 to 29, Table II). This was equivalent to 120,000 international units of vitamin $D$, enough according to Hannon et al. (15) to establish a prolonged remission in osteomalacia. No immediate change in the concentration of serum calcium occurred, nor were the calcium and phosphorus balances or their paths of excretion affected. Believing that the excessive excretion of fatty acid might be interfering with calcium absorption the patient was returned to the low fat diet (III) for three periods of 3 days each (Table II, Periods 30 to 32). As before, there was a very prompt and marked reduction in fecal lipid and reduction in the amount of fecal water, but the time allotted was too short to study adequately the effect on calcium and phosphorus balance. A moderate retention of calcium was observed in Period 31 but Period 32 was spoiled by administration of bile. Twenty days after the last dose of viosterol, the serum calcium had increased from 6.3 to $7.7 \mathrm{mgm}$. per cent and six days later to 9.7 (Figure 1). The interpretation of these changes is uncertain. They may have been caused by a delayed effect of viosterol caused by slow absorption of the oily solution. Another possibility for the delayed action of vitamin $D$ may have been diarrhea produced by administration of bile and lasting until the end of Period 34. Unfortunately, 5 days intervened at the end of this period when no balance studies could be done. Whether calcium and phosphorus retention occurred in this interval is not known. A further complication was introduced by administration of liver extract in Periods 35 to 36 . However, since liver extract did not seem to influence the levels of serum calcium and inorganic phosphorus of the other subjects who received it, we are inclined to minimize its importance.

The inconclusive effects of this experiment are to be contrasted with those obtained on Subjects R. G., P. A., and S. B., who were given the vitamin orally and in much higher dosage. ${ }^{2}$ Subjects $R$. G. and S. B. received the vitamin D concentrate while ingesting Diet VIII. Both subjects had had tetany, and the level of calcium and inorganic phosphorus in the serum was very low when treatment was started.

\footnotetext{
2 The vitamin D concentrate was contributed by the Winthrop Chemical Company, Inc., through the courtesy of Mr. F. E. Houghton. It was described as a solution of crystalline vitamin $D$ in oil having a potency of $1,000,000$ U.S.P. vitamin D units per gram.
} 
The effect on R. G. was prompt. Almost immediately there was an increase in the phosphorus content of the urine (Figure 3 ) followed in a few days by a marked decrease in fecal phosphorus (Table III). The latter more than offset increased urinary excretion and the balance became strongly positive. Fecal calcium also decreased markedly without any appreciable increase in urinary calcium. The net effect was a considerable retention of both elements. The changes in the serum were definite, both calcium and inorganic phosphorus rising toward normal (Figure 2).

The fecal lipids were low on this diet and remained unaffected by the vitamin. After 18 days (Periods 34 to 37 ) butter supplements were added to the diet without producing appreciable change in the composition of the feces. In Period 41 the intake of fatty acid had been increased in this maniner to 91 grams daily and now approached the amount given in the control diet. The latter (Diet VI) was substituted in Period 42 , and symptoms of steatorrhea developed within 24 hours. As Period 30 was comparable to 42 in all respects except for the administration of the vitamin, it served as a useful standard of reference. There was appreciably less steatorrhea in Period 42, and enough calcium and phosphorus were absorbed to produce positive balances. The suggestion is, therefore, rather strong that steatorrhea had been lessened by relief of the vitamin deficiency. The mechanism of the effect remained obscure. It may have been related to better absorption of calcium from the intestine, to decreased intestinal irritability accompanying a higher level of calcium in the blood and tissues, or to some factors at present unknown. Johnson (16) thought that, when viosterol was administered to a patient with an ileal fistula, the rate of propulsion of the contents of the small bowel decreased giving a longer absorptive period.

Case S. B.'s metabolism was followed for a much shorter time, but the data given in Table IV show a similar response to vitamin $D$ therapy.

Case P. A.'s steatorrhea was so mild that there was very little tendency to diarrhea, even while ingesting the diet (VI) to which R. G. gave evidence of marked intolerance. He received the vitamin $D$ concentrate together with the high fat ration in Periods 20 to 27 (Table V). There were no definite signs of $\mathrm{D}$ avitaminosis prior to treatment. Serum calcium and inorganic phosphorus were normal and did not increase with treatment. The excretion of urinary phosphorus increased as it had in the other patients (Figure 3 ), but the main effect was on the feces. Decreased excretion of fecal calcium and phosphorus led to a good retention of both elements. The excretion of fecal fatty acids remained unchanged.

It is evident that the oral administration of a suitable vitamin $D$ concentrate proved an effective means of correcting the calcium and phosphorus deficiencies of severe and mild steatorrhea. The solubility of the vitamin in fats has been suggested as a cause of its poor absorption (17), and seems adequate reason for its administration in connection with a diet that reduces fecal lipids to a low level. This does not necessarily imply the rigid exclusion of dietary fats in all cases (cf., Case P. A.).

With the exception of J. B., it is probable that the dose of vitamin D was considerably greater than necessary. Obviously this point requires further study. Improvement in general health and absence of untoward symptoms seemed to exclude any toxic action.

Once the body has been thoroughly saturated with the vitamin, it is excreted or inactivated quite slowly and continuous administration may not be necessary $(15,18,19)$. One of our patients, R. G., has maintained the calcium and inorganic phosphrus concentrations of his serum at normal levels without additional medication for more than six months. It has perhaps been possible for him to absorb sufficient vitamin D from his diet for maintenance, especially since he has followed dietary instructions faithfully and has had no diarrhea. Patient S. B., on the other hand, has shown a definite tendency to develop hypocalcemia and hypophosphatemia when his food was no longer fortified with viosterol. The time interval involved is not known accurately, but relapse has occurred in less than eleven months (see Case report (8)). Direct comparison of the duration of the vitamin $D$ effect in the two patients is not possible because of the different initial dosage and their different modes of living.

There are some points of interest in regard to 


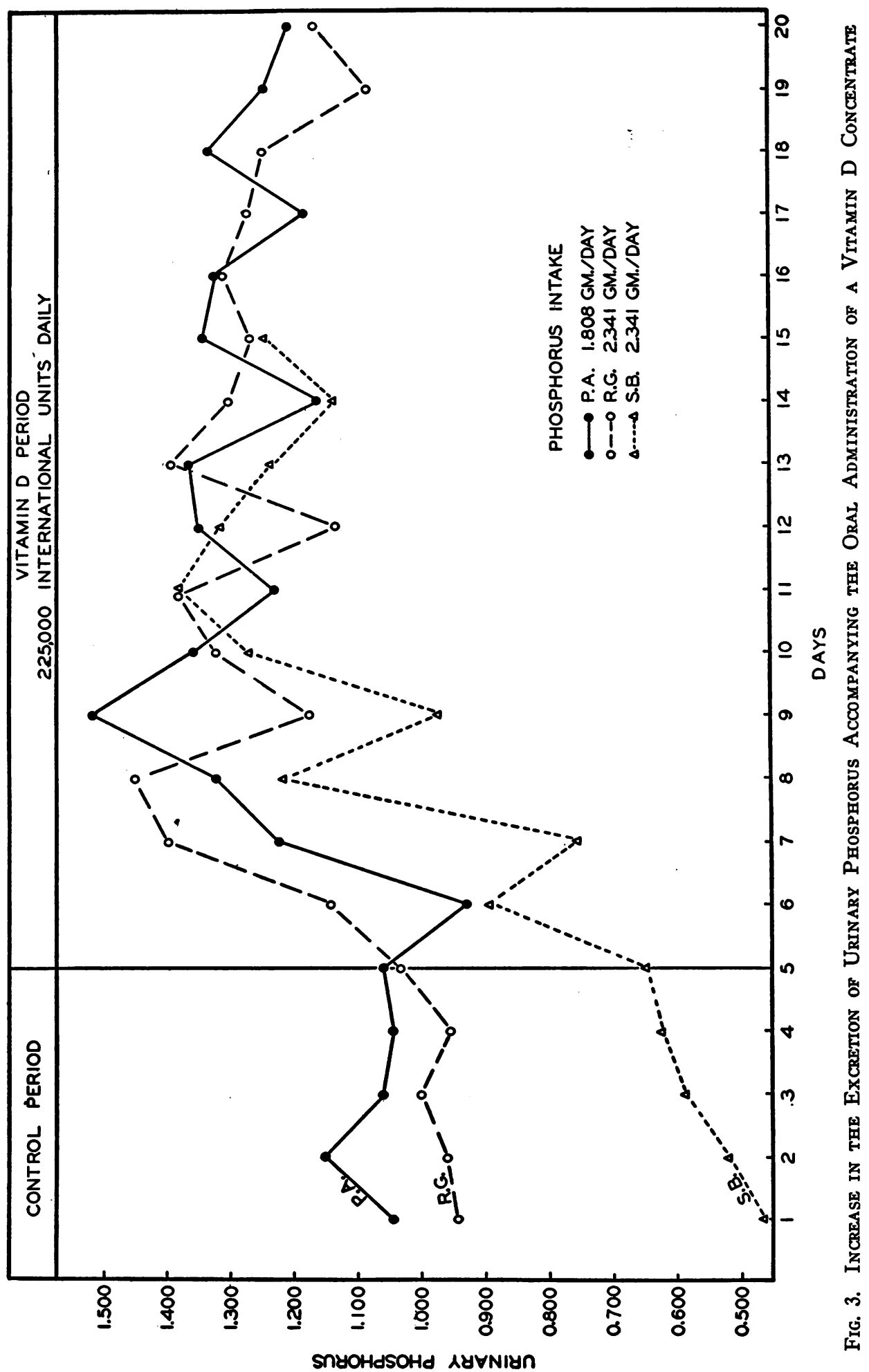


TABLE IV

Case S.B. Effect of vitamin D on calcium and phosphorus metabolism

\begin{tabular}{|c|c|c|c|c|c|c|c|c|c|c|c|c|c|c|c|c|c|}
\hline \multirow{2}{*}{ 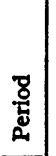 } & \multirow{2}{*}{ 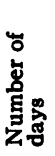 } & \multicolumn{2}{|c|}{ Diet } & \multirow{2}{*}{$\begin{array}{c}\text { Daily } \\
\text { medication }\end{array}$} & \multicolumn{4}{|c|}{ Daily feces } & \multicolumn{3}{|c|}{ Daily calcium } & \multicolumn{3}{|c|}{ Daily phosphorus } & \multicolumn{3}{|c|}{ Serum } \\
\hline & & $\underset{\text { ber }}{\text { Num- }}$ & $\begin{array}{l}\text { Fatty } \\
\text { acid }\end{array}$ & & $\begin{array}{c}\text { Wet } \\
\text { weight }\end{array}$ & \begin{tabular}{|c} 
Dry \\
weight
\end{tabular} & $\begin{array}{l}\text { Total } \\
\text { fatty } \\
\text { acid }\end{array}$ & $\begin{array}{l}\text { Nitro- } \\
\text { gen }\end{array}$ & Urine & Stool & Balance & Urine & Stool & Balance & $\mathbf{C a}$ & $\mathbf{P}$ & $\begin{array}{l}\text { Total } \\
\text { pro- } \\
\text { tein }\end{array}$ \\
\hline & & & $\begin{array}{l}\text { grams } \\
\text { per } \\
\text { day }\end{array}$ & & grams & grams & grams & grams & grams & grams & grams & grams & grams & grams & $\begin{array}{c}\text { mgm } \\
\text { per } \\
\text { cent }\end{array}$ & $\begin{array}{c}\mathrm{mgm} . \\
\text { per } \\
\text { cent }\end{array}$ & $\begin{array}{l}\text { per } \\
\text { cent }\end{array}$ \\
\hline $\begin{array}{l}2 \\
4\end{array}$ & 4 & VIII* & 23.2 & $\begin{array}{l}\text { None } \\
\text { Vitamin D }\end{array}$ & 210 & 58.3 & 17.3 & 3.18 & 0.016 & 2.255 & -0.640 & 0.519 & 1.698 & +0.125 & 6.8 & 2.4 & 4.7 \\
\hline & & & 20.2 & 225,000 I.U. & 170 & J0.0 & 10.2 & 2.20 & 0.010 & 1.J0J & & 0.910 & 1.020 & T0.401 & & & \\
\hline 5 & 4 & VIII* & 23.2 & Vitamin D & 142 & 46.4 & 20.1 & 2.04 & 0.010 & 1.390 & +0.240 & 1.335 & 0.640 & +0.367 & & & \\
\hline 6 & 3 & VIII* & 23.2 & $\begin{array}{l}\text { Vitamin D } \\
\text { 225,000 I.U. }\end{array}$ & 152 & 41.7 & 14.8 & 2.02 & 0.008 & 1.180 & +0.450 & 1.240 & 0.565 & +0.537 & 8.0 & 3.9 & 5.3 \\
\hline
\end{tabular}

* Diet increased 50 per cent.

TABLE V

Case P.A. Effect of vitamn $D$ administration

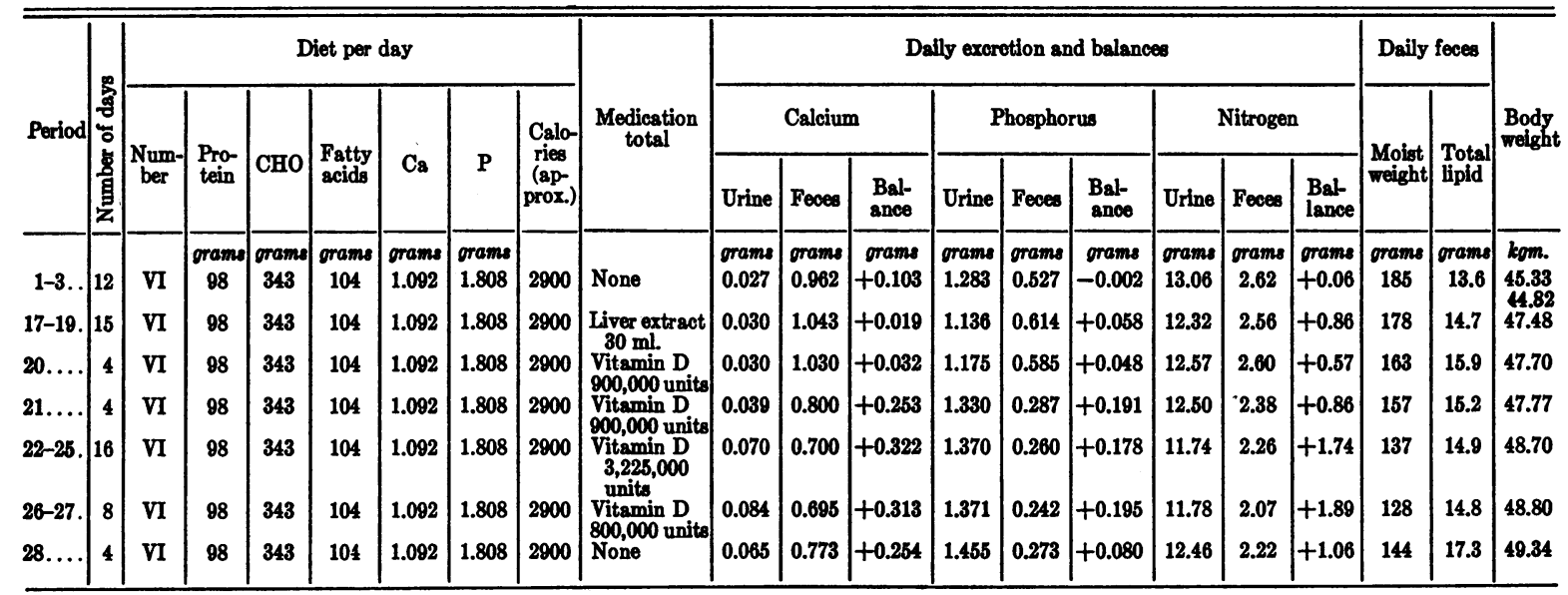

the action of vitamin D which remain to be considered. Albright and Sulkowitch (13) have stated that massive doses of the vitamin increase the excretion of phosphorus in the urine. This effect was particularly noteworthy in Subjects R. G. and S. B. In the latter, the paths of excretion were completely reversed. The phosphorus in the urine during the second period on the vitamin was about 2.5 times as great as during the control period. (Compare Periods 2 and 5, Table IV.) All of this extra phosphorus seems to have been derived from increased absorption from the gut. While the fecal calcium decreased, it was not reduced as much as might have been expected from the decrease in fecal phosphorus. The result of treatment of R. G. was essentially the same. The effect of vitamin
D was clearly apparent in the first period in which it was given (Period 34, Table III). The excretion of phosphorus in the urine increased about $470 \mathrm{mgm}$. a day, but there was little or no change in the fecal excretion of either calcium or phosphorus. An effect on the feces was noted in Period 36. Fecal phosphorus decreased by an average of $768 \mathrm{mgm}$. per day below the control level established in Periods 31 to 33 . Fecal calcium fell $388 \mathrm{mgm}$. below its control level. The actual phosphorus balances of both patients were considerably in excess of the theoretical balances (22). These findings are difficult to reconicile with the view that the increased absorption of phosphorus after vitamin D was entirely secondary to the absorption of calcium. The argument might be raised that the absorption of phos- 
phorus was secondary to the combined absorptions of calcium and magnesium. Reference to Table VI in which it has been assumed that each millimol of phosphorus was combined with 2 m.eq. of base does not point to any considerable participation of magnesium in the absorption of phosphorus. About all that can be said on the basis of the data at hand is that the vitamin, (a) increased excretion of phosphorus in the urine before it affected the fecal excretion, (b) markedly increased the absorption of both $\mathrm{Ca}$ and $\mathrm{P}$ from the gut, and $(c)$ appeared to increase the absorption of magnesium.

TABLE VI

Calcium, magnesium and phosphorus in feces before and during vitamin $D$ administration

\begin{tabular}{c|c|c|c|c|c}
\hline \hline Period & $\mathrm{Ca}$ & $\mathrm{Mg}$ & $\mathrm{Ca}+\mathrm{Mg}$ & $\mathrm{P}$ & Medication \\
\cline { 2 - 4 } & $\begin{array}{c}\text { m.eq. } \\
\text { per. } \\
d a y\end{array}$ & $\begin{array}{c}\text { m.eq. } \\
\text { per } \\
\text { day }\end{array}$ & $\begin{array}{c}\text { m.eq. } \\
\text { per } \\
d a y\end{array}$ & $\begin{array}{c}\text { m.eq. } \\
\text { per } \\
\text { day }\end{array}$ & \\
\hline
\end{tabular}

CASE S.B.

\begin{tabular}{r|r|r|r|r|l}
\hline 2 & 112 & 35 & 147 & 109 & \multicolumn{2}{|c}{ None } \\
4 & 79 & 29 & 108 & 67 & Vitamin D 225,000 \\
5 & 69 & 29 & 98 & 41 & Vitamin D 225,000 \\
6 & 59 & 26 & 85 & 36 & Vitamin D 225,000 \\
\hline
\end{tabular}

CASE R.G.

\begin{tabular}{c|c|c|r|r|l}
\hline $31-33$ & 79 & 29 & 108 & 80 & \multicolumn{2}{|c}{ None } \\
34 & 90 & 31 & 121 & 77 & Vitamin D 225,000 \\
35 & 59 & 24 & 83 & 30 & Vitamin D 225,000 \\
36 & 43 & 29 & 72 & 32 & Vitamin D 225,000 \\
37 & 18 & 15 & 33 & 16 & Vitamin D 225,000 \\
38 & 31 & 26 & 57 & 21 & Vitamin D 225,000 \\
39 & 22 & 18 & 40 & 14 & Vitamin D 225,000 \\
\hline
\end{tabular}

\section{COMMENT}

The development of deficiency states in steatorrhea and in sprue leads to a vicious circle. The function of the gastro-intestinal tract suffers first as a result of some unknown primary disorder impairing its absorptive power and then from malnutrition and specific deficiencies which further reduce the tolerance for foods which cannot be properly digested and absorbed. Clinical recovery may result from relief of recognizable deficiencies such as macrocytic anemia and osteomalacia, if combined with appropriate dietary therapy. The latter permits restitution of bodily tissues and functions affected by malnutrition.

Our experience with liver extract in treatment of two patients, one of whom had hypochromic anemia and mild steatorrhea, the other a very mild macrocytic anemia and severe steatorrhea did not point to a specific action of the extract on the fatty diarrhea. The quantities of extract used were in general comparable to or larger than the amounts found effective in tropical and nontropical sprue by other investigators $(1,2,3,5)$. The essential differences were perhaps that our subjects were nearly free from clinical signs of any deficiency which could unquestionably be relieved by liver, and in addition were kept upon a rigorously controlled diet, proven in each instance to be associated with steatorrhea. It was hoped that the deliberate use of such a diet, the effect of which on the subject was carefully measured in advance, might enable us to distinguish a specific effect of liver extract on steatorrhea, if such existed. The evidence seems to be against a specific effect either on the intolerance for fats or carbohydrates. The latter has been judged by the failure of glucose tolerance to show material improvement (Case reports (8)).

The statement by Verzár (20) that the underlying biochemical defect in steatorrhea is a failure in phosphorylation of fatty acids and glucose awaits clinical confirmation. Since the hypothetical deficiency is a lack of flavin phosphoric acid, and, since liver extract contains this principle (21) one might expect improvement from adequate dosage of liver. Perhaps the amounts we have used were inadequate or the preparation may have been too highly purified (7).

One or more other factors in the vitamin B complex are represented in liver extract. The evaluation of the deficiencies which their lack produces may be difficult or impossible in the human subject particularly when masked by another disease. For example, should the patient with steatorrhea develop the type of digestive disorder not infrequently observed in the pellagrin, then liver extract might prove of considerable benefit, especially since the diarrheal disturbances produced by the two syndromes would probably be additive.

Conjecture as to the probable course of events leading to the $\mathrm{D}$ avitaminosis leaves at least two alternatives: (a) it may be regarded perhaps as among the secondary manifestations of the disease. Malabsorption of fatty acids as suggested 
by Linder and Harris (17) would then be considered primary. The high concentration of intestinal fat provides a medium in which the vita$\min$ is readily soluble and hence its uptake by the intestinal epithelium is impaired. A similar explanation would account for the apparent failure of these patients to absorb a vitamin A concentrate. Diarrhea when present must be included as an additional hindrance to absorption. The delayed absorption of glucose in glucose tolerance tests done in a postabsorptive, state cannot be readily laid to the mechanical effects of fat and seems to point to a more general impairment of the absorptive power of the gut. Possibly tests of the ability to absorb other simple substances would show a similar delay. If this were found to be the case, then the various deficiency states that arise might be regarded as part of a general failure of intestinal absorption which is obviously intensified by diarrhea.

\section{SUMMARY}

1. Prolonged intramuscular administration of liver extract to patients with idiopathic steatorrhea (non-tropical sprue) failed to cause improvement in the absorption of fatty acids, calcium, phosphorus, or nitrogen.

2. In one patient the inverse relationship between calcium and inorganic phosphorus in the serum was fourd when both these elements were at subnormal levels, before vitamin D was administered. In another patient under the same conditions the level of phosphorus in the serum did not change markedly when the serum calcium changed. It is suggested that this difference in behavior may be owing to difference in activity of the parathyroid glands or difference in rate of absorption of phosphorus from the intestine.

3. The oral administration of large doses of vitamin $\mathrm{D}$ caused the following changes:

(a) Increased excretion of phosphorus in the urine before there was evidence of improved calcium absorption.

(b) Increased absorption of calcium from the intestine.

(c) Increased absorption of magnesium from the intestine.

(d) Increased absorption of phosphorus from the intestine. The magnitude of this increase was such that it was probably not entirely secondary to improved absorption of calcium and magnesium.

(e) Some improvement of fatty acid absorption in two patients. This was interpreted as caused by improved calcium absorption or decrease in the rate of propulsion through the small intestine, and probably not to improvement of the primary disorder.

$(f)$ Improvement of absorption of water and nitrogen from the feces. These likewise were interpreted as secondary effects.

\section{BIBLIOGRAPHY}

1. Bloomfield, A. L. and Wyckoff, H. A., Remission in sprue following high liver diet. California and West. Med., 1927, 27, 659

2. Castle, W. B., Rhoads, C. P., Lawson, H. A., and Payne, G. C., Etiology and treatment of sprue. Arch. Int. Med., 1935, 56, 627.

3. Miller, D. K. and Barker, W. Halsey, Clinical course and treatment of sprue. Arch. Int. Med., 1937, 60, 385.

4. Miller, D. K. and Rhoads, C. P., The effect of liver extract on the small intestine of patients with sprue. Am. J. M. Sc., 1936, 191, 453.

5. Hanes, F. M. and McBryde, Angus, Identity of sprue, nontropical sprue and celiac disease. Arch. Int. Med., 1936, 58, 1.

6. Barker, W. Halsey and Rhoads, C. P., The effect of liver extract on the absorption of fat in sprue. Am. J. M. Sc., 1937, 194, 804.

7. Ross, C. W., Intestinal absorption in celiac disease with some remarks on effect of liver extracts upon carbohydrate metabolism. Tr. Roy. Soc. Trop. Med. and Hyg., 1936, 30, 33.

8. Bassett, S. H., Keutmann, E. H., Hyde, H. van Z., Van Alstine, H. E., and Russ, E., Metabolism in idiopathic steatorrhea. I. The influence of dietary and other factors on lipid and mineral balance. J. Clin. Invest., 1939, 18, 101.

9. Peters, J. P. and Van Slyke, D. D., Quantitative Clinical Chemistry. Vol. I. Interpretations. Williams and Wilkins Co., Baltimore, 1931, p. 811.

10. Telfer, S. V., Studies in calcium and phosphorus metabolism. IV. The influence of free fatty acids in the intestine on the absorption and excretion of the mineral elements. Quart. J. Med., 1926, $20,1$.

11. Karelitz, S. and Shohl, A. T., Rickets in rats. II. The effect of phosphate added to the diet of ricketic rats. J. Biol. Chem., 1927, 73, 665.

12. Liu, S. H., Hannon, R. R., Chou, K. G., Chu, H. I., and Wang, S. H., Calcium and phosphorus metabolism in osteomalacia III. The effects of varying levels and ratios of intake of calcium to phosphorus on their serum levels, paths of excretion and balances. Chinese J. Physiol., 1935, 9, 101. 
13. Albright, Fuller and Sulkowitch, Hirsh W., The effect of vitamin $D$ on calcium and phosphorus metabolism; studies on four patients. J. Clin. Invest., 1938, 17, 305.

14. Telfer, S. V., Mineral metabolism in celiac disease. Glasgow M. J., 1928, 109, 306.

15. Hannon, R. R., Liu, S. H., Chu, H. I., Wang, S. H., Chen, K. C., and Chou, S. K., Calcium and phosphorus metabolism in osteomalacia. I. The effect of vitamin $\mathrm{D}$ and its apparent duration. Chinese M. J., 1934, 48, 623.

16. Johnson, Richard M., The absorption and excretion of calcium and phosphorus in three patients with colostomy and ileostomy. J. Clin. Invest., 1937, 16, 223.

17. Linder, G. C. and Harris, C. F., Calcium and phosphorus metabolism in chronic diarrhea with tetany. Quart. J. Med., 1929-30, 23, 195.
18. Heymann, Walter, Metabolism and mode of action of vitamin D. V. Intestinal excretion of vitamin D. J. Biol. Chem., 1937, 122, 257.

19. Windorfer, A., Ueber die Vitamin D Resorption bei Verabreichung hoher Dosen (Vitamin D-stoss). Klin. Wchnschr., 1938, 17, 228.

20. Verzár, F. and Laszt, L., Untersuchungen über die Resorption von Fettsäuren. Biochem. Ztschr., 1934, 270, 24.

Verzár, F., Resorptionsstörungen durch Erkrankungen der Nebennierenrinde. Schweiz. med. Wchnschr., 1937, 67, 823.

21. Elvehjem, C. A. and Koehn, C. J., Studies on vitamin $B_{2}(G)$. The non-identity of vitamin $B_{2}$ and flavins. J. Biol. Chem., 1935, 108, 709.

22. Aub, J. C., Bauer, W., Heath, C., and Ropes, M., Studies of calcium and phosphorus metabolism. III. The effects of the thyroid hormone and thyroid disease. J. Clin. Invest., 1929, 7, 97. 